\title{
Prikazi ljubavi u Andrićevu romanu Na Drini ćuprija
}

Abstract: Katušić Bernarda, Prikazi ljubavi u Andrićevu romanu Na Drini ćuprija (Representation of Love in Andrić's Novel The Bridge on the Drina). "Poznańskie Studia Slawistyczne" 9. Poznań 2015. Publishing House of the Poznań Society for the Advancement of the Arts and Sciences, pp. 275-286. ISSN 2084-3011.

Starting with Erich Fromm's thesis on love from his seminal work The Art of Loving (1956), the paper tries to show the way in which Fromm's psycho-biological concept of love is represented differently in different historical formations in Andrić's historical novel The Bridge on the Drina (1945). A brief analysis of the three love relations from Andrić's novel reveals the process of the appearance of the concept of modern love, the moment in which love ceases to be a social instance and becomes an individual act.

KeYwords: Fromm; Luhmann; Andrić; The Bridge on the Drina; modern love

Kako se, shodno premisama egzistencijalističkog poimanja svijeta i čovjeka, ljudski individuum rađa i umire sam, bez svoje volje, te je kao takav bespomoćno prepušten zakonima prirode i društva, njegova izolirana egzistencija nalik je samotnoj tamnici. Ta svijest o sebi kao odijeljenom entitetu i svijest o ograničenom trajanju vlastitog života izvor je snažne tjeskobe (cf. Jaspers 1967; Kami 1967; Sartre 1983).

U knjizi Umijeće ljubavi Erich Fromm zastupa tezu da je iz navedene egzistencijalne tamnice moguće izaći ujedinjenjem pojedinca s ljudima i svijetom koji su izvan njega, odnosno ljubavlju. Prema Frommu ljubav kao sredstvo nadvladavanja ljudske odvojenosti, kao ispunjenje čežnje za sjedinjenjem nije kakav iracionalan, prolazan osjećajni nalet, nego naše racionalno opredjeljenje, aktivan čin naše volje. „Ljubav je aktivnost, a ne pasivni afekt; ona je svjesno ostajanje uz nekoga, a ne sudbinsko zaljubljivanje. U najopćenitijem smislu, aktivna bi se narav ljubavi mogla opisati tvrdnjom da je ljubav u prvom redu davanje, a ne primanje" (Fromm 2000: 29). 
Tako poimano davanje ne znači ni žrtvu ni kupo-prodaju. Pod davanjem Fromm prije misli darivanje jedne osobe drugoj onog što on naziva život, a manje darivanje materijalnih dobara i praktičnih aktivnosti. Darivanjem $\mathrm{u}$ aktu ljubavi pojedinac drugome daje svoju radost, zanimanje, razumijevanje, znanje, duhovnost ili svoju tugu - sve izraze i manifestacije života u sebi. Dajući tako svoj život drugomu, on ne daje da bi primio, nego obogaćuje drugoga, on time u drugom pojačava osjećaj življenja, ali isto tako i u sebi pojačava taj isti osjećaj (Fromm 2000: 31). Fromm navodi još četiri daljnja polja djelatnosti na kojima pojedinac ostvaruje aktivnu ljubav: briga za drugu osobu, odgovornost prema drugoj osobi, poštovanje i proces stalnog spoznavanja i upoznavanja druge osobe (Fromm 2000: 38). Prema tome tko je ta druga osoba za koju se racionalno opredjeljujemo aktivnim činom ljubavi, Fromm razlikuje nekoliko tipova, odnosno „objekata” ljubavi: bratska ljubav, ljubav između roditelja i djeteta, majčinska ljubav, erotska ljubav, sebeljublje i ljubav prema Bogu. Iako Fromm ne naznačuje eksplicitno prioritet niti jednoga od navedenih tipova ljubavi, na temelju načina kako ih izlaže, kao i prostora kojeg im posvećuje, dade se naslutiti da najviši rang dodjeljuje tipu erotske ljubavi. Naime, slijedom Frommove argumentacije postaje zornim da pojedinac izlaz iz navedene ekzistencijalne tamnice na za njega najzadovoljavajući i najadekvatniji način može pronaći u erotskoj ljubavi, u međusobnom sjedinjenju i stapanju dviju osoba suprotnog spola.

Takva ideja poimanja erotske ljubavi kao odgovora na problem ljudskog postojanja nije nova. Može se reći da je stara koliko i čovjek. Fromm je nalazi već u poznatom mitu prema kojem su muškarac i žena u početku bili poput kugle jedno. Nakon što je nesretnim slučajem ta kugla, to biće, raskoljeno, svaki muškarac traži svoj izgubljeni ženski dio, kako bi se opet sjedinio s njim. Istu misao o početnom jedinstvu spolova nalazimo i u biblijskoj priči o Evi stvorenoj iz Adamova rebra. Shodno tomu Fromm zaključuje da je žudnja za ljubavnim sjedinjenjem dviju osoba suprotnog spola jedna od najsnažnijih težnji u čovjeku. To je jedna od najfundamentalnijih strasti, sila koja na okupu drži ljudski rod, klan, obitelj, društvo. Ne uspije li pojedincu realizirati sebe kroz aktivnu ljubav, on okončava ludilom ili uništenjem -sebe ili drugih. U tom kontekstu Fromm ističe da bez ljubavi ljudski rod ne bi opstao ni dana (Fromm 2000: 25).

Međutim, prema Frommu ne vodi svaki oblik ljubavi potpunom rješenju problema naše egzistencije. Naime, on razlikuje dva oprečna oblika 
ljubavi: ljubav kao zreli odgovor na problem ljudskog postojanja i ljubav kao nezreli, odnosno patološki odgovor na problem ljudskog postojanja. Ključni je preduvjet prve - zrela individua. Daljnja je značajka takve ljubavi da su u njoj očuvana oba osobna integriteta, obje individualnosti. Zrela je ljubav aktivna sila u čovjeku koja istovremeno ruši zidove koji čovjeka dijele od njegova bližnjega, ali i sila koja ga istovremeno sjedinjuje s drugim. U aktivnom činu ljubavi čovjek svladava osjećaj izolacije i odvojenosti, ali istovremeno ostaje ono što jest, zadržava svoj integritet.

Ljubav je moguća samo ako dvoje ljudi međusobno komunicira iz središta svog postojanja, te stoga i samo ako oboje sebe doživljava iz središta svog postojanja. (...) Ljubav, doživljena tako, stalan je izazov; ona nije odmaralište, nego zajedničko gibanje, rad i rast; vlada li među ljudima sklad ili sukob, veselje ili tuga, sve je to sekundarno prema fundamentalnoj činjenici da dvoje ljudi sebe doživljava iz biti svog postojanja, da su oni jedno s drugim zato što su jedno sa samim sobom, zato što ne bježe od samoga sebe (Fromm 2000: 99-100).

Stoga Fromm zaključuje: „U ljubavi se pojavljuje paradoks da dva bića postaju jedno, a ipak ostaju dva" (Fromm 2000: 28).

Fromm razlikuje nekoliko oblika nezrele, odnosno pseudo ili patološke ljubavi. U daljnjem ću tekstu ukratko izložiti samo one koje držim relevantnima za ovdje postavljenu tezu.

1. Ideja o „timu”. Odnos dvoje ljubavnika koji nikada ne uspijeva stići do „odnosa središta”. Obje osobe u odnosu ostaju na površini svoga bića: jedno prema drugome odnose se ljubazno i formalno trudeći se da se taj drugi samo na van dobro osjeća (Fromm 2000: 86).

2. Ideja o uzajamnom spolnom zadovoljavanju. U ovom se ljubavnom obliku polazi od premise da je spolno zadovoljenje polazište i uvjet ljubavnog sjedinjenja, a ne kao u zreloj ljubavi njena prirodna posljedica (Fromm 2000: 87).

3. Neurotična ljubav. Osnovni preduvjet neurotične ljubavi jest da su u njoj jedan ili oba ljubeća i dalje vezana za lik roditelja, pa zbog toga sve osjećaje, očekivanja i strahove što su ih nekoć gajili prema ocu ili majci sada kao odrasle osobe prebacuju na ljubljeno biće (Fromm 2000: 92).

4. Idolatrijska ljubav. Čovjek koji još nije dosegao nivo svijesti o vlastitom identitetu, o jastvu, ukorijenjen u produktivni razvoj vlastitih 
snaga, sklon je ,idoliziranju” voljene osobe. Takav pojedinac otuđen je od vlastitih snaga koje projicira u voljenu osobu te je obožava kao summum bonum, nosioca sve ljubavi, svjetla i blaženstva. Takav pojedinac pritom sebe lišava svakog osjećaja snage, i umjesto da se u voljenoj osobi nađe, on se u njoj gubi. S obzirom na to da obično nitko ne može, bar na dugi rok, živjeti u skladu s očekivanjima svog idolatrijskog obožavatelja, razočaranje je u takvom obliku pseudo ljubavi neizbježno, a njemu se lijek traži u pronalaženju novog idola. Tom je obliku idolatrijske ljubavi svojstvena silina i iznenadnost ljubavnog doživljaja. Takva se idolatrijska ljubav počesto opisuje kao istinska, velika ljubav; pa ipak, usprkos tomu što se njome želi prikazati silina i dubina ljubavi, njome se samo dokazuje glad i očaj idolatra (Fromm 2000: 96).

5. „Sentimentalna ljubav". Njezina se bit svodi na činjenicu da se ta ljubav doživljava samo u mašti a ne i u odnosu, sada i ovdje, prema drugoj stvarnoj osobi (Fromm 2000: 97).

6. Ljubav bez sukoba. Ovaj oblik ljubavi polazi od premise da je moguće živjeti u stalnoj harmoniji svih potreba i želja dvoje ljubavnika.

Polazeći od navedenih Frommovih teza, pokušat ću pokazati kako takvo psihološko-biološko poimanje ljubavi u Andrićevu povijesnom romanu Na Drini ćuprija kroz različite povijesne formacije biva različito akcentuirano zadobivajući i različit izričaj. Analizom triju ljubavnih odnosa koje Andrić locira u različite vremenske i kulturološke kontekste trebalo bi izići na vidjelo kako Frommovo psihološko-biološko poimanje ljubavi poprima značajne kulturološko-sociološke osebujnosti.

\section{Fenomen moderne ljubavi}

Zbog podrobne analize čovjekove egzistencije kao takve, rasvjetljavanja njegovih najskrovitijih psiholoških predjela, kao i postupaka introspekcije protkanima s legendarnim i iracionalnim momentima, Andrićev roman Na Drini ćuprija u stručnoj literaturi nerijetko je označavan kao tipičan modernistički tekst (cf. Ostojić 1977; Zorić 1977; Pogačnik 1981; Šicel 1981; Korać 1989). Ljubav kao jedan od primarnih psihološko-bioloških poriva u čovjeku esencijalna je potka i Andrićeva moderniteta. Stoga 
je način kako je fenomen ljubavi razložen u Andrićevom poetskom svjetonazoru, kao i mjesto koje mu je dodijeljeno u životu svakog pojedinca, predstavljeno s najrazličitijih aspekata. Polazeći od navedene višeslojnosti daljnja analiza usredotočena je na predstavljanje procesa nastajanja koncepta moderne ljubavi, točnije, momenta u kojem ljubav prestaje biti društvena instanca i postaje individualnim činom.

Fenomen moderne ljubavi koji u zapadnoeuropskom kulturnom krugu započinje razdobljem romantizma u stručnoj je literaturi bio pozamašno diskutiran (cf. Fuchs 1999/2003; Illouz 2003; Egen 2009). U tom kontekstu ključnom se nameće studija Liebe als Passion. Zur Codierung von Intimitat (1982) njemačkog teoretika Niklasa Luhmanna.

Polazeći od teorije sistema, Luhmann fenomen moderne ljubavi definira kao jedan od oblika društvene komunikacije, točnije, „kao simbolički generaliziran komunikacijski medij" (Luhmann 1996: 15). Koncept je moderne ljubavi po njemu utemeljen na romantičnoj ljubavi koja nastaje konstituiranjem građanskog društva početkom 18. stoljeća. Suprotno tradicionalnom, odnosno „stratifikacijskom” društvenom poretku, moderno društvo sve se očitije i snažnije „funkcionalno diferencira” u pojedinačne praktike. U takvom društvenom poretku individuum više nije ukorijenjen samo u jednom društvenom segmentu, nego istovremeno u čitav niz najrazličitijih područja.

U prijelazu iz stratifikacijskog u funkcionalno diferenciranje društva najprije dolazi do snažnijeg diferenciranja osobnih i socijalnih sistema (što točno uzevši znači: do razlika sistem/okolina za osobne odnosno socijalne sisteme). Razlog: u funkcionalnom diferenciranju pojedina osoba više ne može biti naseljena u jednom i samo jednom podsistemu društva, nego se mora pretpostaviti da je socijalno nesmještena (Luhmann 1996: 12).

Tako, primjerice, moderni pojedinac nije samo član obitelji, nego je istovremeno socijaliziran u okvirima svoje profesije, slobodnog vremena i najrazličitijih aktivnosti. Prema tome, svaka pojedina osoba prisiljena je kako na stalno kretanje tamo-amo između različitih područja kojima pripada, tako i na stalno mijenjanje uloga koje su mu dodijeljene. „Štoviše, pojedinac mora naći potvrdu na razini svog sistema osobnosti, a to znači: u razlici prema svojoj okolini i u načinu na koji s njom postupa za razliku od drugih" (Luhmann 1996: 13). U takvoj društvenoj konstelaciji 
modernom je pojedincu iznimno teško konstituirati vlastiti identitet. Osobna i intimna komunikacija ne samo da su otežane, nego vremenom bivaju sve rjeđe.

Luhmann polazi od toga da svaka pojedina osoba navedeni problem identiteta najadekvatnije može riješiti ljubavlju kao aktom potpunog obostranog prihvaćanja drugoga sa svim njegovim različitostima i posebnostima. Identično Frommu i Luhmann vjeruje da je tek takvim kompletnim prihvaćanjem drugoga moguće međusobno potvrđivanje i ostvarivanje vlastitog bitka kao i pripadnosti svijetu ${ }^{1}$. Dok, međutim, Fromm pri definiciji ljubavi polazi od čovjekova psihološko-biološkog ustroja motreći je kao bezvremensku instancu, Luhmann ljubav motri kao kulturološko-sociološku datost nalazeći tek u modernom konceptu ljubavi snagu i mogućnost izlaženja iz egzistencijalne tamnice. U skladu s tim Luhmann razlikuje moderni koncept ljubavi utemeljen na osjećaju pojedinca, na njegovoj intimnoj sferi i potrebama, te njegovu slobodnom izboru, od ljubavnog koncepta koji mu je prethodio, a koji se može nazvati tradicionalnim ili kolektivnim. U takvom ljubavnom konceptu potrebe pojedinca podređene su društvenom sustavu, obitelji ili široj sociološkoj zajednici te su utemeljene na unaprijed utvrđenim moralnim kodeksima ponašanja ${ }^{2}$.

Kako bih u Andrićevu romanu Na Drini ćuprija naznačila promjenu od tradicionalnog prema modernom konceptu ljubavi, ukratko ću analizirati tri ljubavna odnosa.

${ }^{1}$ Takvo poimanje fenomena ljubavi kao oblika realizacije ljudske individue u aktu sjedinjenja $\mathrm{s}$ individuom suprotnog spola učestali je topos recentnih promišljanja ljubavnog diskursa (cf. Pieper 1972: 42; Lewis, Amini, Lannon 2009: 10, 260).

${ }^{2}$ Proces ,individualizacije i diferencijacije” modernog društva Luhmann prati od srednjeg vijeka do romantizma. Dok je u srednjem vijeku ljubav poimana kao duhovni čin koji čovjeka vodi k Bogu, s renesansom ljubavni odnos počinje biti individualiziran jer više ne počiva na relaciji individuum-Bog, nego na relaciji muškarac-žena. Navedeni proces individualizacije dobiva u 17. stoljeću nove impulse. Rasprostranjenošću tiska ljubav postaje autoreferencijalnim sustavom. Međutim, tek od romantizma ljubav počiva na strastvenim čulima i slobodi ljubavnog izbora oba ljubeća. Romantičnim ljubavnim toposom ujedno se poistovjećuje seksualnost s ljubavlju. Kako Andrić u romanu Na Drini ćuprija, u svojevrsnoj povijesnoj kronici bosanskog društva i čovjeka, ne diferencira navedena dijakrona razdoblja, naša analiza koncentrirana je, kao što je već istaknuto, na moment nastanka moderne ili individualne ljubavi supsumirajući sva prethodna razdoblja pojmom tradicionalne ili kolektivno-patrijahalne ljubavi. 


\section{Ljubav između Fate i Naila}

Ljubavna priča između Fate i Naila događa se u starijim turskim vremenima. Fata je djevojka iznimne ljepote i posebnog društvenog statusa. Njezina je obitelj jedna od najuglednijih i najimućnijih u kasabi. Zbog njezine ljepote i njezina socijalnog statusa, kao i zbog samosvijesti i nepristupačnosti, Fata je najpoželjnija djevojka u gradu. O njezinoj ljepoti i posebnosti svjedoči i narodna pjesma koja je ostala u kolektivu još dugo nakon njezina života ${ }^{3}$. Nail, sin jedne druge vrlo imućne i cijenjene obitelji iz kasabe, kao i većina mladića, zaljubljen je u Fatu. Njihova ljubavna priča počinje pri slučajnom susretu kada joj on kao usput kaže da će uskoro biti njegova supruga, što Fata prezirno i odlučno odbija. Sukob između mladićeve želje i djevojčina odbijanja zaoštravaju roditelji koji međusobno dogovaraju brak između Fate i Naila. Kako je i na koji način dogovoren brak, akteri nisu nikad saznali. „Šta je bilo između Avdage Osmanagića i Mustajbega Hamzića, kako je Mustajbeg zatražio Fatu za svog jedinca Naila i kako mu je preki i častoljubivi Avdaga «dao» djevojku? To nikad niko neće saznati" (Andrić 1977: 127).

Fata bez prigovora prihvaća očevu riječ i, barem naizgled, sve funkcionira kako su se roditelji dogovorili. Kao što očekuju ustaljeni običaji sredine, Fata sudjeluje u svim pripremama za svadbu i reklo bi se da ih čak obavlja s radošću. Međutim, prava drama odvija se navečer kada ostane sama.

Rastrganost egzistencije kojoj je uskraćen poriv za voljeti i biti voljen, poštivajući osobne emocije i intimni sustav, Andrić vrlo uvjerljivo crta introspektivno predstavljajući njezinu nutrinu. Fatina drama proizlazi iz činjenice da ona nije kadra ni raskinuti ni prihvatiti patrijarhalne okove. Fata, naime, prihvaća očevu odluku dobrovoljno, iz ljubavi prema njemu, ali istovremeno svoju intimnost ne može dijeliti s čovjekom kojeg joj je otac odabrao.

Opisima Fatine unutrašnjosti neposredno pred vjenčanje izlazi na vidjelo Fatina borba sa sudbinom, rascijep između intimne želje i potrebe te potreba i interesa socijalnog sustava . U besanoj noći Fata čuje očev kašalj i proživljava sljedeće:

${ }^{3}$ „Mudra li si, lijepa li si, / Lijepa Fato Avdagina!” (Andrić 1977: 123). 
To je njen dragi, moćni, jedinstveni bâbo, sa kojim se oseća jedno, nerazdeljivo, slatko jedno, otkako zna za sebe. I sam taj njegov teški i potresni kašalj oseća u svojim grudima. Istina, to su ta usta koja su kazala da tamo gde je ona kazala ne. Ali ona je u svemu jedno sa njim, pa i u tome. I to njegovo da ona oseća kao svoje (isto koliko i svoje ne). I zato je njena sudbina preka, neobična, sutrašnja, i zato ona na njoj ne vidi izlaza, a ne može ni da ga vidi, kad ga nema. (...) Tu na mrtvoj tački, između svoga ne i očeva da, između Veljeg Luga i Nezuka, tu, na najbezizlaznijem mestu treba tražiti izlaz (Andrić 1977: 129-130).

U konačnici Fata ne nalazi izlaz i izvršava samoubojstvo. Na sam dan vjenčanja, na putu prema Nailovoj kući, na mostu iznenada izlazi iz svečane povorke i baca se u Drinu. Ne mogavši podnijeti nanesenu bol, ubrzo nakon toga, tjelesno i duhovno potpuno uništen, smrtno skončava i Fatin otac.

Očito je da se ljubavni odnos između Fate i Naila ne može označiti kao ,zrela ljubav” u Frommovu smislu. Ne samo snažnim utjecajem i vezanošću za roditelje, nego primarno površnim susretom, izostankom bilo kakve aktivne interakcije i stoga nemogućnošću prodiranja u drugu osobu, navedeni ljubavni odnos može se prema Frommovu određenju ljubavi označiti kao patološki. Kako ljubavni par ne uspijeva zadovoljiti jednu od najfundamentalnijih potreba ljudskog bića - potrebu za ljubavlju, za sjedinjenjem s drugom osobom u obliku zrele ljubavi - oni skončavaju uništenjem. Kako sebe, tako i drugih.

\section{Ljubav između Feduna i Jelenke}

I u ljubavnom odnosu između Feduna i Jelenke evidentno se radi o patološkom obliku u Frommovu smislu. Ovaj ljubavni odnos također vodi ludilu i uništenju sebe i drugih. Ljubavna priča između Feduna i Jelenke odvija se u četvrtoj godini austrijske okupacije. Fedun je mladić ruskog podrijetla koji u kasabi boravi poslovno. Nakon austrijske okupacije vrlo brzo izbijaju nemiri u susjednoj Srbiji i Bosni. Na Višegradskom mostu, koji je u to vrijeme funkcionirao kao granica koja je štitila Austro-Ugarsku od širenja nemira, straža je trebala znatno pojačanje. Fedun je pripadnik austrijske vojske koji dolazi u bosanski gradić kako bi radio na mostu kao stražar. Na straži slučajno ugleda muslimansku djevojku, Jelenku, u koju se na prvi pogled fatalno zaljubljuje. Već na jednom od prvih susreta 
djevojka traži od Feduna da joj pomogne prevesti preko mosta njenu staru majku bez potrebne dokumentacije. Zaslijepljen ljubavlju mladić pristaje ne znajući da je u liku stare majke prerušen jedan od zloglasnih srpskih pobunjenika, poznati hajduk Jakov Čekrlija. Nakon raskrinkavanja prijevare mladić je otpušten iz službe i mora napustiti grad. Ne mogavši se uhvatiti u koštac sa sudbinom, izvršava samoubojstvo.

Idoliziranje voljene osobe, kao i doživljavanje ljubavi samo u mašti, a ne u odnosu sada i ovdje, ne u aktivnom činu prema drugoj osobi, upućuju na patologiju ljubavnog odnosa između Feduna i Jelenke. Dok tragedija ljubavnog odnosa između Fate i Neila proizlazi isključivo iz patrijahalnih normi zajednice, patologija ljubavnog odnosa između Feduna i Jelenke više je posljedica lomova na području intimne sfere pojedinca. Iako su susreti ljubećih i semantika njihove komunikacije ritualizirani kodeksom ponašanja patrijahalnog društvenog ustroja - Fedun i Jelenka sastaju se tajno, njihova ljubav onemogućena je jer pripadaju različitim kulturama i religijama - njihova ljubav zadobiva patološke oblike primarno jer između $\mathrm{Fe}$ duna i Jelenke ne dolazi do aktivne interakcije. Naime, Fedun Jelenku ne doživljava kao realno biće, nego kao summum bonum, imaginarnu iluziju, ideal svekolike ljepote i ljubavi. Suprotstavljanjem navedenih dvaju tipova ljubavi Andrić naznačuje razliku i mijenu od tradicionalnog, kolektivno-patrijarhalnog koncepta ljubavi prema individualno modernom.

\section{Ljubavni trokut Zorke, Glasinčanina i Stikovića}

Navedeni proces individualizacije ljubavnog odnosa Andrić nadalje naznačuje predstavljajući ljubavni trokut među učiteljicom Zorkom, njezinim kolegom Glasinčaninom i mladim studentom Stikovićem. Ta ljubavna priča događa se neposredno pred Prvi svjetski rat, u najmlađim austrijskim vremenima. Suprotno prvim dvjema ljubavnim pričama koje - iako na različite načine - primarno bivaju onemogućene faktorima izvana, kolektivnim normama i stegama, tragika ljubavnog trokuta među Zorkom, Glasinčaninom i Stikovićem u potpunosti počiva na individualnim razlozima i motivima.

Još u početnoj fazi ljubavnog odnosa između Zorke i Glasinčanina, još u fazi „gledanja”, Zorka istovremeno počinje vezu sa Stikovićem. Pri 
jednom od prvih susreta nasamo, u vrlo neobičnim uvjetima, u napuštenim školskim prostorijama, između praznih đačkih klupa i stolica, bez prethodne komunikacije, aktivne interakcije i prodiranja u drugoga, Zorka i Stiković vode ljubav. Nakon seksualnog odnosa oboje su nezadovoljni i potišteni. Ne zbog rušenja kolektivnih moralnih kodeksa, nego jer im izabrani oblik ljubavi ne donosi osobno ispunjenje. Iz tijeka priče vrlo brzo izlazi na vidjelo da Stiković nije sposoban voljeti jer sam nije zrela osoba. Stiković odlazi iz kasabe. Nakon nekoliko površnih pisama Zorki potpuno mu se gubi trag. Spoznavši da ljubi Stikovića, ali da joj ta ljubav nije uzvraćena, Zorka psihički i fizički propada, dolazi do granica ludila, razmišlja o suicidu.

Ponovno je u život vraća Glasinčaninova požrtvovna i nesebična ljubav. Međutim, vrlo brzo izlazi na vidjelo da je i ta ljubav osuđena na propast jer je jednostrana. Ljubav Glasinčanina, ma kako snažna i požrtvovna bila, Zorku zadovoljava samo privremeno. Priča završava tako da Glasinčanin odlazi u rat, a Zorka ostaje sama. Suprotno prvim dvjema ljubavnim pričama u kojima do realizacije zrele ljubavi u Frommovom smislu, do međusobnog sjedinjenja i stapanja ljubavnika ,iz središta” njihova bića ne dolazi zbog normativnog kodeksa patrijahalnog društvenog poretka, kao razlog ljubavnog neuspjeha u ljubavnom trokutu Zorke, Glasinčanina i Stikovića mogu se navesti samo osobni motivi: ne prodiranje do središta, nesređenost osoba, nedostatak uzajamne ljubavi.

Predstavljaljući navedena tri ljubavna odnosa u povijesnom kontinuitetu, Andrić naznačava liniju emancipiranja ljubavnika iz socijalne sredine iz kojih potječu. Približavajući se modernim vremenima, ljubavni se odnosi sve više individualiziraju i definiraju na osnovi principa diferencije. Samoodređenje individuuma na temelju razlike između društvenog sustava i druge individue paralelno je sa sve većim posvjetovljenjem i naglašavanjem tjelesne strane ljubavi.

Analiza provedena iz vizure Frommova poimanja ljubavi pokazuje da se nijedan od triju ljubavnih odnosa prikazanih u Andrićevu romanu Na Drini ćuprija ne može odrediti kao zreli oblik ljubavi. Evidentno je da ni u jednoj ljubavnoj koncepciji nije predstavljen ljubavni odnos u kojem bi ljubeći komunicirali iz „središta” svog postojanja. Iako zbog različitih razloga, ni jedan ljubavni odnos ne uspijeva pronaći koncepte zadovoljavanja temeljnog egzistencijalnog poriva izlaska iz zatvora vlastite 
egzistencije aktivnim ljubavnim sjedinjenjem s drugom osobom. Također ostaje zornim da niti u jednom od ljubavnih odnosa prestavljenih u Andrićevu romanu, ni u patrijarhalnim ni u modernim društvenim sustavima, makar iz suprotnih razloga, ne dolazi do potpunog sjedinjenja dviju osoba suprotnog spola zbog čega se može reći da Frommova odredba ljubavi funkcionira prije kao nedostižan ideal nego kao psihološko-biološka konstanta. Stoga se nameće pitanje: nije li i Frommovo psihološko-biološko određenje ljubavi tek idealan kulturološki konstrukt njegova (našeg) vremena?

\section{Literatura}

Andrić I., 1977, Na Drini ćuprija, Sarajevo.

Đuvić M., 2007, Ljubav između dva rata (Konstrukti o ljubavi u bosanskohercegovačkih pripovjedača između dva svjetska rata), u: Prikazi ljubavi u bosanskoj, hrvatskoj i srpskoj književnosti. Od renesanse do danas, ur. R. Hodel, Frankfurt am Main, str. 293-303.

Egen Ch., 2009, Zur Sozio- und Psychogenese der romantischen Liebesvorstellung in westeuropäischen Gesellschafte, Göttingen.

Fromm E., 2000, Umijeće ljubavi, prev. H. Lisinski, Zagreb.

Fuchs P., 1999/2003, Liebe, Sex und solche Sachen. Zur Konstruktion moderner Intimyssteme, Konstanz.

Hodel R., 2007, Ljubav u konfliktu između dva socijeteta (Lazarević, Stanković, Andrić, Krleža, Rudan), u: Prikazi ljubavi u bosanskoj, hrvatskoj i srpskoj književnosti. Od renesanse do danas, ur. R. Hodel, Frankfurt am Main, str. 211-229.

Illous E., 2003, Der Konsum der Romantik. Liebe und die kulturellen Widersprüche des Kapitalismus. Frankfurt-New York.

Jaspers K., 1967, Filozofija egzistencije, prev. M. Cekić, I. Ivanji, Beograd.

Kami A., 1987, Mit o Sizifu, prev. N. Smailagić, Sarajevo.

Korać S., 1989, Andrićevi romani ili Svijet bez Boga, Zagreb.

Lewis T., Amini F., Lannon R., 2009, Opća teorija ljubavi, prev. M. Vilišić, Zagreb.

Luhmann N., 1982, Liebe als Passion. Zur Codierung von Intimitat, Frankfurt am Main.

Luhmann N., 1996, Ljubav kao pasija: o kodiranju intimnosti, Zagreb.

Ostojić K., 1977, Andrićevo prevazilaženje apsurda, u: Ivo Andrić u svjetlu kritike, ur. B. Milanović, Sarajevo, str. 281-288.

Petković S., 2007, Ljubav u srpskoj pripoveci s početka 20. veka, u: Prikazi ljubavi u bosanskoj, hrvatskoj i srpskoj književnosti. Od renesanse do danas, ur. R. Hodel, Frankfurt am Main, str. 229-241.

Pieper J., 1972, Über die Liebe, München. 
Pogačnik J., 1981, Andrićeva radikalizacija tradicije romana, u: Delo Ive Andrića u kontekstu evropske književnosti i kulture, ur. D. Nedeljković, Beograd, str. 111-121 .

Sartr Ž.P., 1983, Biće i ništavilo: ogled iz fenomenološke ontologije, Beograd.

Šicel M., 1981, Modernistička faza Ive Andrića, u: Delo Ive Andrića u kontekstu evropske književnosti i kulture, ur. D. Nedeljković, Beograd, str. 129-139.

Zorić P., 1977, Metafizički realizam Ive Andrića, u: Ivo Andrić u svjetlu kritike, ur. B. Milanović, Sarajevo, str. 298-305. 